\title{
Antimicrobial properties of various solvents combinations for phytochemical fraction derived from Uncaria gambier extract against Enterococcus faecalis ATCC 29212
}

\author{
Gita Dwi Jiwanda Sovira ${ }^{1 *}$, Marry Siti Mariam², Mieke Hemiawati Satari ${ }^{3}$ \\ 'Biomedical Science Graduate Program, Faculty of Medicine Universitas Padjadjaran, Indonesia \\ ${ }^{2}$ Department of Oral Biology, Faculty of Dentistry Universitas Padjadjaran, Indonesia
}

\begin{abstract}
Introduction: Enterococcus faecalis is often found in root canal infections and can cause failure in root canal treatment. Uncaria gambier is an herbal medicine that is known to be rich in polyphenol compounds that have antibacterial properties. Because of the polyphenol content and antibacterial properties of Uncaria gambier, it can be an alternative as an antibacterial solution for root canal treatment. The purpose of this study is to analyze the antimicrobial of various solvents combinations for phytochemical fraction derived from Uncaria gambier extract against Enterococcus faecalis (ATCC 29212). Methods: This study is descriptive explorative research Uncaria gambier was extracted using a combination of three different fractions, ethyl acetate-water, hexane-water and hexane-ethyl acetate. We determine the Minimum Inhibitory Concentration (MIC) and Minimum Bactericidal Concentration (MBC) against Enterococcus faecalis (ATCC 29212) using the serial microdilution method and by add test samples to the Mueller Hinton agar medium from each fraction Results: Combination Ethyl Acetate-water has MIC value at $0.195 \mathrm{mg} / \mathrm{ml}$, combination Hexane-water at $0.049 \mathrm{mg} / \mathrm{ml}$ and combination Hexane- Ethyl Acetate have the MIC value at $1.563 \mathrm{mg} / \mathrm{ml}$. The MBC value in combination Ethyl Acetate-water at 25 $\mathrm{mg} / \mathrm{ml}$, combination Hexane-Ethyl Acetat and Hexane-water $M B C$ value at $50 \mathrm{mg} / \mathrm{ml}$ and $100 \mathrm{mg} / \mathrm{ml}$. Based on optical density measurement using ELISA Reader and bacterial growth on the media used, the fraction combinations increase the antibacterial effect of Uncaria gambier against E. faecalis ATCC 29212. Conclusion: The combination of various Uncaria gambier solvents has been shown to inhibit and kill E. faecalis (ATCC 29212). The combination of Ethyl Acetate-water fraction is the best combination to against $E$. faecalis (ATCC 29212). It means that the combination of various Uncaria gambier solvents can be developed as alternative root canal irrigation.
\end{abstract}

Keywords: Enterococcus faecalis; Uncaria gambier; fraction combination; MIC; MBC.

p-ISSN: 1979-0201; e-ISSN: 2549-6212; Available from: http://jurnal.unpad.ac.id/pjd/article/view/23907

DOI: 10.24198/pid.vol33no1.23907

Submission: Oct 14, 2019; Accepted: Jan 05, 2021; Published online: Mar 31, 2021

\footnotetext{
*Corresponding author: Gita Dwi Jiwanda Sovira, Biomedical Science Graduate Program, Faculty of Medicine Universitas Padjadjaran, Indonesia. 38, Jalan Professor Eyckman, Bandung, West Java, Indonesia, 40132. Phone: +62 811-6609-174; e-mail: gitasovira@gmail.com
} 


\section{INTRODUCTION}

Enterococcus faecalis is often found in root canal infections and can cause failure in root canal treatment. This bacterium is a persistent root canal microorganism. ${ }^{1,2,3}$ The prevalence of $E$. faecalis in root canal infection is $40 \%$ and varies from $24 \%$ to $77 \%{ }^{3,4}$ This is due to its ability to compete with other microorganisms and its ability to invade dentinal tubules, which can protect $E$. faecalis from chemo-mechanical root canal preparation, and intra-canal dressing techniques. ${ }^{2,5}$

Root canal irrigation plays an important role in reducing the amount of $E$. faecalis. ${ }^{2}$ One of the irrigation materials that are often used is chlorhexidine, but it has negative effects such as discoloration of the teeth and tongue, reduces the sensation of sweet, irritates the oral mucosa and causes dryness of the mouth. ${ }^{6}$ The irrigation material used must be able to get rid of bacteria and neutralize bacterial products without damaging the tissue.

Therefore the most appropriate irrigation material is an irrigation material that has a high antibacterial effect, without damaging the tissues. ${ }^{6}$ One of them comes from herbs, it is called gambier. This is in accordance with the research by Noveri et al which showed that the extract and fraction of gambier leaves contain alkaloids, terpenoids, steroids, flavonoids, phenolics and saponins, where the flavonoids in uncariagambier have bactericidal properties that can kill bacteria by damaging bacterial cell membranes. and denatured bacterial cell proteins. ${ }^{7}$

Gambier (Uncariagambier Roxb.), is a medicinal plant that has long been known and used by Indonesian. Phytochemical components in gambier leaves are flavonoids, saponins, triterpenoids, tannins, and alkaloids, with the largest component being flavonoids. ${ }^{8}$

One of the active ingredients of the gambier isolate is flavonoids, which can kill bacteria by damaging bacterial cell membranes and denaturing bacterial cell proteins. ${ }^{8}$ The ability of gambier in killing bacteria can inhibit $E$. faecalis, so gambier can be used as an irrigation agent in root canal treatment. ${ }^{9}$

Extraction and fractionation of herbs can separate polyphenol content in those plants. ${ }^{10,11}$ This research will use methanol, hexane, water and ethyl acetate as a solvent to fractionate the polyphenols in gambier fruit. Fractionation can increase or decrease the biological activity of herbal extracts, depending on the interaction of the polyphenol content on the extract when used in combination. ${ }^{12}$

The purpose of this study is to analyze the antimicrobial of various solvents combinations for phytochemical fraction derived from Uncaria gambier extract against Enterococcus faecalis (ATCC 29212).

\section{METHODS}

\section{Bacterial Strain and Inoculum Preparation}

The bacterial culture of $E$. faecalis strain (American Type Culture Collection, ATCC 29212) was obtained from a chemical laboratory, Faculty of Chemistry, Universitas Padjadjaran. For the inoculum preparation, one inoculating loop of bacteria was grown in liquid Brain Heart Infusion (BHI) and incubated at $37^{\circ} \mathrm{C}$ for 24 hours under anaerobic condition using the anaerobic jar. The bacteria suspension was then diluted until it reached the standard of 0.5 McFarland standard $\left(0.5 \times 10^{8} \mathrm{CFU} / \mathrm{ml}\right)$.

\section{Preparation of Extracts and Fraction of Uncaria Gambier Roxb}

A total of 1250.6 grams of gambier fruit obtained from West Sumatra were cut into small pieces and extracted by the maceration method with methanol as a solvent for $3 \times 24$ hours. The mixture is then filtered using filter paper and evaporated with an evaporator until all the solvents are gone. After the drying process is complete, the gambier flavonoid extract powder will be obtained. Then partitioned with hexane, ethyl acetate, and water to get each fraction.

\section{Phytochemicals Screening}

The crude methanolic extracts and fraction of UncariaGambier Roxb were screened for the presence of phytochemical compound according to the procedure described by Harbone. ${ }^{13}$ Phytochemical reagent added to the extract and fraction solution. The qualitative results are expressed as $(+)$ for the presence of a phytochemical compounds and (-) for the absence of a phytochemical compounds. 
Determination of the Minimum Inhibitory Concentration (MIC)

The combinations between gambier fruit fractions to be tested were divided into three groups, group 1 is a combination of $n$-hexane and ethyl acetate fractions, group 2 is a combination of $n$-hexane and water fractions, and group 3 is a combination of ethyl acetate and water fractions. Each fraction is combined with a concentration ratio of $1: 1$. The positive control used was gambier fruit methanol extract and chlorhexidine solution, while the blank of bacterial culture media was used as a negative control. Antibacterial test to obtain the MIC value from the combination between gambier fruit fractions against $E$. faecalis was obtained using a microdilution method then measured turbidity or optical density using the ELISA Reader, referring to the procedure described by Eloff with a slight modification.

The procedure is carried out with replication twice.Then the result was calculated using the comparison formula from the distribution of the sample OD (sample + media + bacteria), OD blank sample (sample + media) The Minimum Inhibitory Concentration is taken as the lowest concentration of the sample solution that can inhibit bacterial growth characterized by the beginning of clarity in the sample solution and bacteria.

\section{Determination of the minimum bactericidal concentration (MBC)}

The Minimum Bactericidal Concentration is taken as the lowest concentration of the sample solution that can kill $100 \%$ of bacteria grown on Mueller Hinton agar plates at a concentration after the MIC. A total of $100 \mu \mathrm{l}$ of media suspension, samples and bacteria from the MIC concentration, two concentrations above the MIC and two concentrations below the MIC were poured over the media so that the Mueller Hinton was in the middle. Then the suspension is spread evenly over the surface of the media using a spreader. Then incubated for 24 hours at $37^{\circ} \mathrm{C}$, in an anaerobic atmosphere using an anaerobic jar. After 24 hours, removed and observed the presence or absence of bacterial growth on the surface of the Mueller Hinton agar plate. MBC concentration value is determined from the concentration of no bacterial growth in the media.

\section{RESULTS}

\section{Extract and Fractionation}

Gambier fruit totaling $1250.6 \mathrm{~g}$ was obtained from West Sumatra. Samples obtained macerated then obtained gambier fruit methanol extract as much as $269.6 \mathrm{~g}$. The methanol extract was fractionated with water, hexane and ethyl acetate. Each obtained a water fraction of $10.3215 \mathrm{~g}$, a hexane fraction of $3.2154 \mathrm{~g}$ and an ethyl acetate fraction of $161.1574 \mathrm{~g}$.

\section{Phytochemical screening}

Phytochemical screening results show that Uncariagambier extracts and fractions contain bioactive substances in the form of flavonoids, triterpenoids, steroids, tannins, saponins and alkaloids. Each extract and fraction of Uncariagambier contains different bioactive ingredients, as shown in table 1.

Table 1. Phytochemical test results of Gambir fruit

\begin{tabular}{|c|c|c|c|c|c|c|}
\hline \multirow{2}{*}{ No } & \multirow{2}{*}{ Secondary Metabolites } & \multirow{2}{*}{ Test Method ${ }^{13}$} & \multicolumn{4}{|c|}{ Test Results in Faction } \\
\hline & & & Water & Hexane & Ethyl Acetate & Metanol \\
\hline 1 & Flavonoid & $\mathrm{Mg}+\mathrm{HCl}$ concentrated & + & - & + & + \\
\hline 2 & Triterpenoid & Lieberman-burchard & - & + & + & + \\
\hline 3 & Steroid & Lieberman-burchard & - & + & - & - \\
\hline 4 & Tanin & $\mathrm{FeCl}_{3} 1 \%$ & + & - & + & + \\
\hline 5 & Saponin & Water $+\mathrm{HCl}$ & + & - & + & + \\
\hline 6 & Alkaloid & Dragendorff reagents & + & - & + & + \\
\hline
\end{tabular}

From table 1, it can be seen that each fraction draws different polyphenol contents, which correspond to their polarity. Ethyl acetate fraction most interesting polyphenol compounds in gambier fruit. While the steroid content in gambier fruit is only obtained from the hexane fraction. This shows that when a combination of fractions is carried out, the polyphenol content 
of herbal plants obtained will be more diverse. ${ }^{7}$ Determination of MIC and MBC ValuesAntibacterial test to obtain the MIC value from a combination of gambier fruit fractions against $\mathrm{E}$. faecalis was obtained using the microdilution method then measured turbidity or optical density using the ELISA Reader, referring to the procedure described by Eloff with slight modifications. ${ }^{14}$

Table 2. MIC percentage of Uncaria gambier fraction combination against $E$. faecalis

\begin{tabular}{|c|c|c|c|c|c|}
\hline No & Concentration $(\mathrm{mg} / \mathrm{ml})$ & EA & HA & HE & Chx \\
\hline 1 & 100.00 & $3.10 \%$ & $6.45 \%$ & $3.23 \%$ & $1.61 \%$ \\
\hline 2 & 50.00 & $3.45 \%$ & $12.28 \%$ & $6.14 \%$ & $3.07 \%$ \\
\hline 3 & 25.00 & $3.50 \%$ & $17.50 \%$ & $8.75 \%$ & $4.38 \%$ \\
\hline 4 & 12.50 & $9.15 \%$ & $13.98 \%$ & $6.99 \%$ & $3.49 \%$ \\
\hline 5 & 6.250 & $10.85 \%$ & $17.28 \%$ & $8.64 \%$ & $4.32 \%$ \\
\hline 6 & 3.125 & $3.55 \%$ & $15.13 \%$ & $7.56 \%$ & $3.78 \%$ \\
\hline 7 & 1.563 & $3.40 \%$ & $15.45 \%$ & $7.73 \%$ & $3.86 \%$ \\
\hline 8 & 0.781 & $3.55 \%$ & $15.08 \%$ & $7.54 \%$ & $3.77 \%$ \\
\hline 9 & 0.390 & $3.40 \%$ & $16.15 \%$ & $8.08 \%$ & $4.04 \%$ \\
\hline 10 & 0.195 & $3.40 \%$ & $15.25 \%$ & $7.63 \%$ & $3.81 \%$ \\
\hline 11 & 0.098 & $3.40 \%$ & $16.45 \%$ & $8.23 \%$ & $4.11 \%$ \\
\hline 12 & 0.049 & $3.35 \%$ & $13.83 \%$ & $6.91 \%$ & $3.46 \%$ \\
\hline
\end{tabular}

EA: combination of Ethyl Acetate and Water fractions, HA: Hexane and Water,

HE: Hexane and Ethyl Acetate, Chx: Chlorhexidine

The results can be seen in table 2 . The table above, the MIC value of the combination of the EA Uncaria gambier fraction against $E$. faecalis is at a concentration of $0.195 \mathrm{mg} / \mathrm{ml}$.

Whereas the combination of HA Uncaria gambier fraction is $0.049 \mathrm{mg} / \mathrm{ml}$, and the combination of HE Uncaria gambier fraction is also found at a concentration of $1.563 \mathrm{mg} /$ $\mathrm{ml}$. Minimum bactericidal concentration (MBC) is seen by observing the presence or absence of bacterial growth on the surface of agar plates. $M B C$ concentration values are determined from the concentration of no bacterial growth in the media.

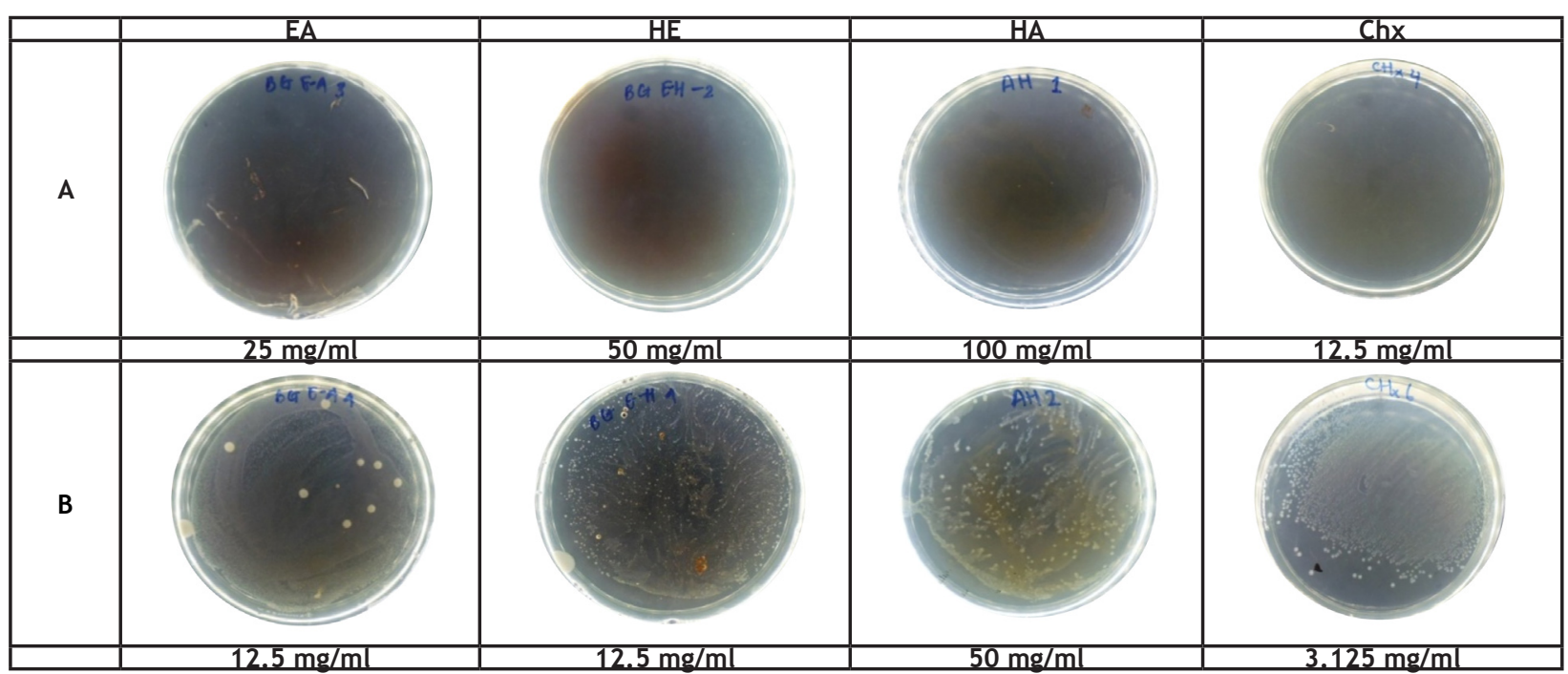

Figure 1. MBC values were obtained from subcultures from microtiter plates to the surface of Mueller Hinton agar medium. A. Clean microtiter plates. There is no bacteries on the surface. B. Bacteries on the surface of microtiter plates

Fgure 1, the lowest $M B C$ value was found in a combination of EA fraction at $25 \mathrm{mg} /$ $\mathrm{ml}$, followed by the combination of HE fraction at $50 \mathrm{mg} / \mathrm{ml}$, and combination of HA fraction at $100 \mathrm{mg} / \mathrm{ml}$. However, chlorhexidine still has the lowest $M B C$ value at $12.5 \mathrm{mg} / \mathrm{ml}$. 


\section{DISCUSSION}

The main chemical component in Uncaria gambier is a group of flavonoid compounds. ${ }^{15}$ Flavonoids function as antibacterial by forming complex compounds against extracellular proteins that disrupt the integrity of bacterial cell membranes and denaturing bacterial cells. ${ }^{8,16,17}$ The phytochemical test of gambier fruit can be seen in table 1. Phytochemical test results showed that the methanol extract of gambier fruit contained Flavonoids, Triterpenoids, tannins, saponins, and alkaloids. Gambier fruit water fraction contains flavonoids, tannins, saponins, and alkaloids. The hexane fraction of gambier fruit contains triterpenoids and alkaloids. While the gambier fruit ethyl acetate fraction contains flavonoids, triterpenoids, tannins, saponins, and alkaloids. The results of this bioactive compound content are supported by previous research which states that the bioactive compounds contained in gambier fruit have antibacterial and antioxidant properties. ${ }^{15,1820}$

Crude extracts contain complex mixtures of several bioactive compounds with different solubility properties, which selectively dissolve in the appropriate solvent. This follows the principle of solubility, "like dissolves like", which are compounds with the same polarity will be dissolved from each other. ${ }^{21}$ In this study, bioactive compounds from gambier fruit methanol extracts are separated according to their solubility through the fractionation process using hexane (nonpolar) solvents. ,ethyl acetate (semi-polar) and water (polar). Fractionation can separate bioactive compounds from extracts, increase purity and their activity.

The type of solvent for extraction and its polarity properties greatly influence the concentration of polyphenol compounds obtained. The polarity of polyphenol compounds ranges from polar to non-polar, optimal extraction is usually obtained in polar solvents which have better solvation efficiency as a result of interactions (hydrogen bonds) between polar points of antioxidant compounds and solvents from nonpolar ones. ${ }^{10,11}$ Extracts from plants are a mixture of different polyphenol compounds, these compounds will be selectively dissolved in the solvent according to their polarity. Fractionation is used to separate bioactive compounds from extracts and increase their purity. Fractionation of this extract will increase the potential biological activity of plants. The type of solvent used in fractionation will also affect the polyphenol content obtained and the biological activity of the plant. ${ }^{10,11}$ This study proved that fractionation has separated gambier fruit bioactive compounds according to their polarity. Water (polarity index 9.0 ) which has polar properties can dissolve flavonoids, tannin saponins, and alkaloids. Ethyl acetate (polarity index 4.4) which has semi-polar properties can dissolve most bioactive compounds, namely flavonoids, triterpenoids, tannins, saponins, and alkaloids. Whereas hexane (polarity index 0.0 ) only dissolves the active compounds triterpenoids and steroids. The difference in polarity of the solvent determines the different types and composition of phytochemical compounds. Solvents can also affect the antimicrobial activity of herbal plants. ${ }^{22,23}$

The chemical ingredients in gambier that are most widely used are catechins and tannins. Catechins are oligomeric procyanidin (OPC) tannin compounds classified as flavonoids. Flavonoids function as antibacterial by forming complex compounds against extracellular proteins that interfere with the integrity of bacterial cell membranes and denaturing bacterial cells. ${ }^{8,19}$

Flavonoids are polar, making it easier to penetrate the peptidoglycan layer which is also polar in gram-positive bacteria than in the nonpolar lipid layer in gram-negative bacteria. In addition, gram-positive cell walls containing polysaccharides (teichoic acids) are watersoluble polymers. This solubility indicates that the gram-positive cell wall is more polar. The inhibitory activity of antibacterial compounds in gambier against gram-positive bacteria causes the disruption of the function of the cell wall as a giver of cell shape and protects cells from osmotic lysis. Disruption of cell walls will cause cell lysis. ${ }^{8}$

Results of the study shows it can be seen that the combination of gambier fruit fractions has the ability to inhibit the growth of $\mathrm{E}$. faecalis at different concentrations. The combination of $10 \%$ Water-Ethyl Acetate fraction can inhibit the growth of E. faecalis at a concentration of 0.195 $\mathrm{mg} / \mathrm{ml}$. Combination of $10 \%$ Water-Hexane fraction at a concentration of $0.049 \mathrm{mg} / \mathrm{ml}$. While the 
combination of $10 \%$ Ethyl Acetate-Hexane fraction at a concentration of $1.563 \mathrm{mg} / \mathrm{ml}$. This result is influenced by the content of bioactive compounds found in each solvent. ${ }^{23}$ The polarity of the solvent plays an important role in increasing the solubility of the bioactive compound. ${ }^{10,11,24,25}$ The difference in the polarity of the solvent determines the difference in the type and composition of the phytochemical compounds. Solvents can also affect the antimicrobial activity of herbal plants. Different solvents will have different antibacterial effects. ${ }^{11,22,25,26}$

The killing power of each fractions combination against $\mathrm{E}$. faecalis also has different values. MBC combination of $10 \%$ Water-Ethyl Acetate fraction is at a concentration of $2.5 \%$. MBC combination of $10 \%$ Ethyl Acetate-Hexane fraction is present at a concentration of $5 \%$. While the MBC combination of $10 \%$ Air-Hexane fraction is found at $10 \%$. However, the MIC and MBC values of each fraction combination were still above the chlorhexidine MIC and MBC values of E. faecalis. The chlorhexidine MIC value of $\mathrm{E}$. faecalis was at $0.625 \%$ while the value of $M B C$ chlorhexidine against $E$. faecalis at $1.25 \%$. Nevertheless the combination of gambier fruit fractions can still be used as a root canal irrigation material because of its ability to inhibit and kill E. faecalis.

The results of this study were also supported by several previous studies that showed gambier leaf crude extract at a concentration of $100 \%$ can inhibit the growth of E. coli. ${ }^{8}$ In the Salmonella typhimurium and Staphylococcus aureus ATCC 29213 test bacteria, the concentration of gambier leaf rough extract was able to inhibit each its growth until $90 \%$ and $100 \% .{ }^{8}$ Previous research by santoso et all. stated that $6 \%$ gambier extract was able to kill $100 \%$ of S. mutans. ${ }^{27}$ Research by Amos reported that at a concentration of $24 \%$ mouthwash containing gambier had antibacterial activity. ${ }^{17}$ Lucida et al, mentioned that toothpaste containing $7 \%$ gambier extract has optimal antimicrobial power in inhibiting the growth of $\mathrm{S}$. mutans as a cause of dental plaque formation. ${ }^{28}$

\section{CONCLUSION}

The combination of various Uncaria gambier solvents has been shown to inhibit and kill $E$. faecalis (ATCC 29212). The combination of Ethyl
Acetate-water fraction is the best combination to against E. faecalis (ATCC 29212). It means that the combination of various Uncaria gambier solvents can be developed as alternative root canal irrigation.

\section{REFERENCES}

1. Hugar S, Patel PM, Nagmoti J, Uppin C, Mistry L, Dhariwal N. An in vitro Comparative Evaluation of Efficacy of Disinfecting Ability of Garlic Oil , Neem Oil , Clove Oil , and Tulsi Oil with autoclaving on Endodontic K Files tested against Enterococcus faecalis. Int $\mathrm{J}$ Clin Pediatr Dent. 2017;10(3):283-8. DOI: $10.5005 /$ jp-journals-10005-1451

2. Anuradha B, Indira R, Lalitha MK, Sriram T. A New Irrigant against $E$. faecalis in Root Canal Disinfection. Biosci Biotechnol Res Asia. 2014; 11(1): 121-7.

3. Varadan P, Ganesh A, Konindala R, Nagendrababu V. Comparison of the Antibacterial Efficacy of Alexidine and Chlorhexidine Against Enterococcus Faecalis : An in Vitro Study. Cureus. 2017; 9(10): 1-6. DOI: $10.7759 /$ cureus. 1805.

4. Tonea A, Badea M, Oana L, Sava S, Vodnar D. Antibacterial And Antifungal Activity of Endodontic Intracanal Medications. Clujul Med. 2017; 90(3): 344-7. DOI: 10.15386/ cjmed-750.

5. Jhajharia K, Parolia A, Shetty KV, Mehta LK. Biofilm in endodontics: A review. J Int Soc Prev Community Dent. 2015; 5(1): 1-12. DOI: 10.4103/2231-0762.151956.

6. Hajimaghsoodi $S$, Zandi $H$, Bahrami $M$, Hakimian R. Laboratory Comparison of the Anti-Bacterial Effects of Spearmint Extract and Hypochlorite Sodium on Enterococcus Faecalis Bacteria. J Dent Biomater. 2016; 3(4): 322-6.

7. Rahmawati N, Rahmah M. Antibacterial from crude extract of gambier leaves (Uncaria gambir var (ubadak) microwave-assisted extraction method against pathogenic. Ind Che Acta. 2014; 4(2): 32-5.

8. Magdalena NV, Kusnadi J. The effect of gambier (Uncaria gambir R.) on the healing of burns in male white mice (Mus musculus L.). J Pangan dan Agroindustri. 2015; 3(1): 124-35. 
9. Merta I, Nuidja I, Marwati N. Gambier extract has an inhibitory power against the growth of Staphylococcus aureus in vitro. J Skala Husada. 2013; 10(1): 39-43. DOI: 10.22146/ tradmedj.7944

10. Thouri A, Chahdoura H, Arem A El, Hichri AO, Hassin R Ben, Achour L. Effect of solvents extraction on phytochemical components and biological activities of Tunisian date seeds ( var . Korkobbi and Arechti ). 2017; p. 1-10.

11. Anokwuru CP, Anyasor GN, Ajibaye O. Fakoya O. Okebugwu P. Effect of Extraction Solvents on Phenolic, Flavonoid and Antioxidant activities of Three Nigerian Medicinal Plants. 2011; 9(7): 53-61. DOI: $10.5897 /$ JMPR2016.6271

12. Nwodo UU, Iroegbu CU, Ngene AA, Chigor VN, Okoh Al. Effects of Fractionation and Combinatorial Evaluation of Tamarindus indica Fractions for Antibacterial Activity. 2011; 16(6): 4818-27. DOI: $10.3390 /$ molecules 16064818

13. Laraib S, Sharif S, Bibi Y. Phytochemical Analysis and Some Bioactivities of Leaves and Fruits of Myrsine africana Linn. Arab J Sci Eng. 2021; 46: 53-63. DOI: 10.1007/s13369-02004710-4

14. Eloff JN. A sensitive and quick microplate method to determine the minimal inhibitory concentration of plant extracts for bacteria. Planta Medica. 2016; 64(8): 711-713. DOI: 10.1055/s-2006-957563.

15. Sumoza NS, Efrizal, Rahayu R. The effect of gambier (Uncaria gambir R.) on the healing of burns in male white mice (Mus musculus L.). J Biol Univ Andalas. 2014; 3(4): 283-8.

16. Rusdiana S, Dewi P, Marlamsya DO, Bikarindrasari R. The anticaries effect of gambier extract on male Wistar rats. Maj Kedokt Gigi Indones. 2017;3(2):83-92. DOI: 10.24198/pjd.vol24no3.26832gal13112

17. Lukas A. Formulasi obat kumur gambir dengan tambahan peppermint dan minyak cengkeh. J Din Pen Indust. 2012; DOI: 10.28959/jdpi. $\underline{\text { v23i2.606 }}$

18. Aditya M, Ariyanti PR. Benefits of Gambir ( Uncaria gambir Roxb ) as Antioxidant. Majority. 2016; 5(3): 129-33.

19. Septiani D, Yuslianti ER, Nasroen SL. Effect of Ethanol Extract of Gambir (Uncaria Gambir) Leaves Compared with Topical 0.2\% Chlorhexidine Gluconate on Healing. Dentika Dent J. 2015; 18(3): 262-7. DOI: 10.32734/ dentika.v18i3.1973

20. Alamanda TP, Aditya M, Dokter MP, Kedokteran F, Lampung U, Ilmu B, et al. Benefit of Gambir for Acne Treatment. Major. 2016; 5(3): 173-7.

21. Sarker SD, Nahar L. Chemistry for Pharmacy Students General, Organic and Natural Product Chemistry. $1^{\text {st }}$ ed. Wiley; England. 2014. p. 368

22. Widyawati PS, Dwi T, Budianta W, Kusuma FA. Difference of Solvent Polarity To Phytochemical Content and Antioxidant Activity of Pluchea indicia Less Leaves Extracts. J Bio Univ Andal (J. Bio. UA.) 2014; 6(4): 850-5.

23. Etame RE, Mouokeu RS, Laurel C, Pouaha C, Kenfack IV, Tchientcheu R, et al. Effect of Fractioning on Antibacterial Activity of Enantia chlorantha Oliver ( Annonaceae ) Methanol Extract and Mode of Action. Evidence-Based Complement Altern Med. 2018; 10(1155): 13. DOI: $10.1155 / 2018 / 4831593$

24. Boeing JS, Barizão EO, E Silva BC, Montanher $\mathrm{PF}$, de Cinque Almeida V, Visentainer JV. Evaluation of solvent effect on the extraction of phenolic compounds and antioxidant capacities from the berries: application of principal component analysis. Chem Cent J. 2014; 8(1): 48. DOI: 10.1186/s13065-0140048-1.

25. Koffi E, Sea T, Dodehe Y, Soro S. Effect of solvent type on extraction of polyphenols from twenty three Ivorian plants. J Anim Plant Sci. 2011; 5(3): 550-8.

26. Hiruy B, Getu E. Efficacy of solvent extracts of Calpurnia aurea ( Ait .) Benth and Milletia ferruginea ( Hochest) Baker leaves against maize weevils, Sitophilus zeamais (Motsch .) of stored maize in Ethiopia. 2018; 9(3): 27-35.

27. Santoso B, Tampubolon $\mathrm{OH}$, Wijaya A, Pambayun R. Interaction of $\mathrm{pH}$ and Unrica gambir Roxb Extract in the Production of Antibacterial Edible Film. Agritech. 2014; 34(1): 8-13. DOI: 10.22146/agritech.9516

28. Lucida H. Formulasi Sediaan Antiseptik Mulut dari Katekin Gambir. J Sains Tek Farm. 2010; 12(1): 25-31. 